

\title{
TRAVEL PREFERENCES OF FINNISH CROSS-BORDER TOURISTS: OPPORTUNITIES AND LIMITATIONS FOR RUSSIAN KARELIA
}

\author{
Svetlana V. Kondrateva ${ }^{1}$ (D) Ekaterina A. Shlapeko² \\ Department of Regional Economic Policy, Institute of Economics \\ Karelian Research Centre, Russian Academy of Sciences \\ 50 Al. Nevsky Prospect, 185030 Petrozavodsk: Republic of Karelia, Russia \\ e-mails: ${ }^{1}$ svkorka@mail.ru (corresponding author) • ${ }^{2}$ shlapeko_kate@mail.ru
}

\begin{abstract}
The study aims to examine travel preferences of Finnish cross-border tourists with special reference to the Republic of Karelia, Russia. Data were collected using paper-based and online surveys from 300 respondents travelling from Finland to the Russian Karelia. Although cross-border tourists are a significant part in the inbound tourist flow to Russian Karelia, several obstacles for this type of tourism have been revealed. Measures to stimulate Finnish tourists to travel to Russian Karelia are suggested. The results of this study can be used to improve Karelian tourist products by providing services as expected by tourists. The findings are limited to visitors of Russian Karelia and should therefore be interpreted with caution.
\end{abstract}

\section{Key words}

cross-border tourism • Finnish cross-border tourists - Republic of Karelia $\bullet$ travel preferences $\bullet$ border region

\section{Introduction}

Finland shares approximately $1,340 \mathrm{~km}$ land border with Russia (with several crossing checkpoints), which is the European Union's longest external border. The Republic of Karelia, located in North-West Russia, has only one foreign neighbor and the longest stretch of the border between the Russian Federation and the European Union (Finland, more than $700 \mathrm{~km}$ ). Finnish Karelia, together with a part of Russian Karelia, was a historical province of the Grand Duchy of Finland within the Russian Empire, and is now divided between Finland and Russia, often simply called Karjala in Finnish. Nowadays, links between people on both sides of the border are comprised of daily communication and cooperation practices, stimulating cross-border mobility and various exchanges.

The article focuses on the study of cross-border tourism practices of Finns in the border region of Russia, the Republic of Karelia. The high share of Finnish tourists in the tourist 
traffic from abroad makes the Karelian tourist industry strongly dependent on variations in the inbound traffic from Finland and raises the significance of the challenges for cross-border tourism. A declining number of Finnish tourists visiting Russian Karelia lately is a reason to find out the travelers' preferences in order to stimulate the inbound tourist traffic as well as the local tourism market. Thus, the main aim of the article is to identify the travel preferences of Finnish cross-border tourists in the context of existing limitations as well as the opportunities available in the Republic of Karelia, and to suggest measures for attracting tourists and revitalizing the economy of this Russian border region.

The empirical data used in this study is a set of 300 anonymous questionnaires that were conducted in Finnish. The feedback illustrates how Finnish visitors view the factors of choice, comfort, and preferred product items. In fact, it is the first study of the travel preferences of Finnish border tourists and of the limitations in Russian Karelia for cross-border tourism development based on sociological research.

\section{Cross-border tourism in the border region: theoretical aspects}

In the studies on the development of tourism in border areas, researchers use the "crossborder tourism" concept as a specific form of tourism development (Timothy \& Butler, 1995; Stepanova, 2014; Makkonen, 2016; Li et al., 2018: Chow \& Tsui, 2019; Boonchai \& Freathy, 2020).

Cross-border tourism sensu lato, is as specific form of tourism development which is only typical of regions having a special economic and geographical location (sharing a border with another state) based on tourist flow from neighboring state(s) (Więckowski, 2010; Stepanova, 2014; Więckowski \& Cerić, 2016; Chow \& Tsui, 2019). In the Karelian case, cross-border tourism is the flow of Finnish citizens to the Republic of Karelia with different tourism purposes (leisure, shopping, visiting relatives and friends, etc.) from one-day trips to longer visits.

The studies of cross-border tourism have generally approached tourist mobility as beneficial for the regional and local development, identifying the strengths as well as limitations for its further growth (Więckowski, 2010; Makkonen, 2016; Stepanova \& Shlapeko, 2018; Stepanova, 2019b; Chow \& Tsui, 2019).

The relationships between tourism activities and cross-border shopping have been investigated more (e.g., Kreck, 1985; Timothy \& Butler, 1995; Wang, 2004; Wachowiak \& Engels, 2006; Sullivan et al., 2012). These studies often take the form of a case study and are predominantly framed as two-country cases: Denmark-Germany (Makkonen, 2016), Switzerland-Germany (Ramsey et al., 2019), Poland-Germany (Malkowski et al., 2020; Szytniewski \& Spierings, 2018). A number of studies have tried to understand the main factors determining satisfaction of tourists with their shopping experience (Egresi, 2017). Previous research proposed methods for studying tourists' satisfaction or dissatisfaction with modern retail centers (Mitríková et al., 2016), how souvenir shopping influences travel experience and economic impact of cross-border travelers (Kusdibyo, 2016; Boonchai et al., 2020). There are several papers investigating everyday shopping practices and recognition of changes in global, translocal, and personal statuses. Based on the results of the Konstanz (Germany) and Kreuzlingen (Switzerland) study, Daug et al. (2019) confirm that cross-border shopping is more than simply shopping, the proposed model of cross-border shopping tourism differs from others in that it illustrates a multilayered experience, including shopping but also leisure, services, atmosphere, and cultural experience. Special attention has also been paid to the travel preferences and characteristics that influence and explain why tourists choose to return (Makkonen, 2016). Based on studies devoted to the differences created by the border, we recognise that various products, prices, atmosphere can 
be important drivers for the cross-border practices (Spierings \& Van der Velde, 2013; Szytniewski et al., 2017).

Discussions on the Russian (Soviet)-Finnish tourism have mostly concentrated on the selected types of Finnish tourism in the USSR and from the early 1990s on the current Russian tourists' interests in Finland. One of the first studies devoted to the background of Finnish tourists in the USSR (Leningrad Region) was conducted by Finnish sociologist H. Palosuo in 1976 (Kostiainen, 1999). Since the early 1990s, the socio-economic transformation and changes in Russia have served as an impetus for the growing academic attention to the Russian (Soviet)-Finnish borderlands and tourism development. Along with an increasing role of tourism in the local economy of the Finnish borderland, the significance of the studies that assess tourists' motivations and cross-border tourism of Russians has increased. Thus, in comparison to the thorough and multifaceted studies of the issue in the Finnish borderland (Käyhty, 1999; Gurova, 2012; Izotov \& Laine, 2013; Gurova \& Ratilainen, 2015, 2016; Björn, 2015; Hannonen, 2016; Laine, 2017; Stepanova \& Shlapeko, 2018; Studzinska et al., 2018; Prokkola, 2010, 2019), the tourist flow of Finnish citizens to Russian (Soviet) borderland territories is practically unstudied, and the results are fragmented. Several studies have focused on selected aspects of Finnish tourism in Soviet Estonia (Kostiainen, 1999; Lauren, 2014; McKenzie, 2016) and in the city of Vyborg (Shikalov \& Hämynen, 2013; Shikalov, 2016). The opportunities to improve the shopping process for Russian tourists and to increase income due to the use of the Russian language have been presented in several papers (Gurova, 2012; Stepanova \& Shlapeko, 2018).

The cross-border tourism mobility in the Karelian part of the Finnish-Russian borderland and its influence on the local development has been revealed in some studies (Izotov \& Laine, 2015; Laine, 2017; Stepanova, 2014, 2019b). Selected aspects of the crossborder tourism of Finns in local areas of the
Russian Karelian part of the borderland have also been presented (Eskelinen et al., 1994; Björn, 2015; Stepanova, 2019a). A few studies have investigated the modern conditions as well as the historical aspects of this type of tourism in the Karelian part of Russia (Nesterova, 2009, 2012; Stepanova \& Shlapeko, 2018). Despite the scientific interest in the cross-border mobility in the Finnish-Russian borderlands, research on Finnish travelers in Russian Karelia is limited to a small number of studies devoted to some aspects of this type of tourism. Taking into account the significant role of Finnish travelers in the tourist traffic to the Republic of Karelia, this study undertakes to bridge the gap in the research on Finnish tourists in the Russian borderland and to fully understand the travel preferences of Finns in order to offer actions for stimulating cross-border tourism.

\section{Karelian borderland as a research area}

The Republic of Karelia is located in NorthWest Russia, and its western boundary coincides with the national border of the Russian Federation with Finland (about 723 km); the region is washed in the north-east by the White Sea. The total area of the Republic is 180.5 thousand square kilometers (1.06\% of the total territory of Russia). Half of the territory is covered with forest, a quarter is water surfaces. There is a total of more than 60 thousand lakes (including the largest lakes in Europe - Ladoga and Onego) and more than 23 thousand rivers. The population is 614,100 people (as of 1 January 2020). There are more than 2.8 thousand nationallist heritage sites in the Republic of Karelia (as of 30 July 2021 (Objects of cultural ..), several of them included in the UNESCO World Heritage List (Kizhi Pogost, Petroglyphs of Lake Onega and the White Sea).

Because of its borderland location, the history of the Republic of Karelia is full of dramatic events, wars, changing of the national border. For example, Finnish Karelia, together 
with a part of Russian Karelia, was a historical province of the Grand Duchy of Finland, within the Russian Empire, and is now divided between Finland and Russia, often simply called Karjala in Finnish. In the 1990s, the political and socio-economic changes taking place in Russia worked to enhance the contact function of the national border, including relaxation of the visa regime. From the 1990s onwards, the cross-border mobility, including tourism, started to gain in significance. For border areas, restrictions on economic activities as well as on the movement of people pose a challenge for cross-border tourism development (Order of the Federal... 2017). E-visa system has been introduced in order to ease the visa application process for foreign citizens visiting Russia (including via the Vyartsilya checkpoint - see Characteristics...). Nowadays, links between people on both sides of the border are comprised of daily communication and cooperation practices, stimulating cross-border mobility and various exchanges.

Along the Karelian part of the Russian-Finnish border, Manakov et al. (2020) identified three cross-border tourism and recreation regions of different development levels: South Karelia, Middle Karelia and North Karelia (Fig. 1). According to the Finnish Border Guard Service, the Karelian section takes about one-fifth the border traffic across the Russian-Finnish national border. From 2012 to 2019, the inbound tourist flow from Finland to the Republic decreased by $23.9 \%$. In the same period, the Karelian part of the Russian-Finnish border was on average crossed by $1,986,898$ people per year. The largest share of the traffic (71.6\% or $1.1 \mathrm{mln}$ passengers, 2019) was serviced by the Vyartsilya-Niirala international checkpoint (South Karelia). The Mid-Karelian second-order microregion has virtually formed around the LyuttyaVartius checkpoint (382.7 thousand crossings in 2019). Its Russian part includes the town of Kostomuksha and the Kalevala District; the Finnish part is the Kainuu region. The Suoperya-Kuusamo checkpoint
(55.2 thousand crossings in 2019) is witnessing the emergence of the North Karelia third-order microregion. This microregion is described as third-order because it is limited to the border areas of the neighbouring districts of Russia and Finland - the western part of the Loukhi District in Karelia and the north-eastern fringe of North Ostrobothnia in Finland, including the city of Kuusamo. Modern challenges of the COVID-19 pandemic have had a crucial impact expressed in a sharp decline in cross-border tourist traffic in 2020-2021.

The cross-border tourism development has the opposite trend. Along with a steady upward trend in the number of Russian citizens visiting Finland (except decline under the geopolitical and economic factors, 2014 2016), a decreasing tourist flow of Finnish citizens to Russian Karelia has been observed in the last ten years (Fig. 2). In 2015 (JanuaryOctober), the Finns' share of border crossings increased to $31 \%$, the highest figure in more than ten years (Laine, 2017: 192). This trend emphasizes the significance of studying the preferences of the travelers from the neighbouring country in order to attract tourists and revitalize the local economy.

North-West Russia as a whole and the Republic of Karelia in particular can be considered as attractive tourist destinations for Finnish citizens. For instance, during 20162019 the Republic of Karelia served a half of the inbound tourist flow of Finns to the Russian Federation on average. This is due to several factors, such as a long shared border, history, socio-cultural features, family contacts, as well as economic reasons.

Retrospectively, the first type of crossborder tourism to the region (except SovietFinnish tourist exchanges, 1920-1990) can be described as Finnish nostalgia tourism (Eskelinen et al. 1994; Gromov 2003; Izotov \& Laine 2013; Laine \& Van der Velde, 2017; Stepanova 2019a). The number of the Finnish tourists coming to the Republic of Karelia increased to 700,000 a year (Gromov 2003; Stepanova 2019a), this was a period of the 'rediscovery of Karelia', with a boom 


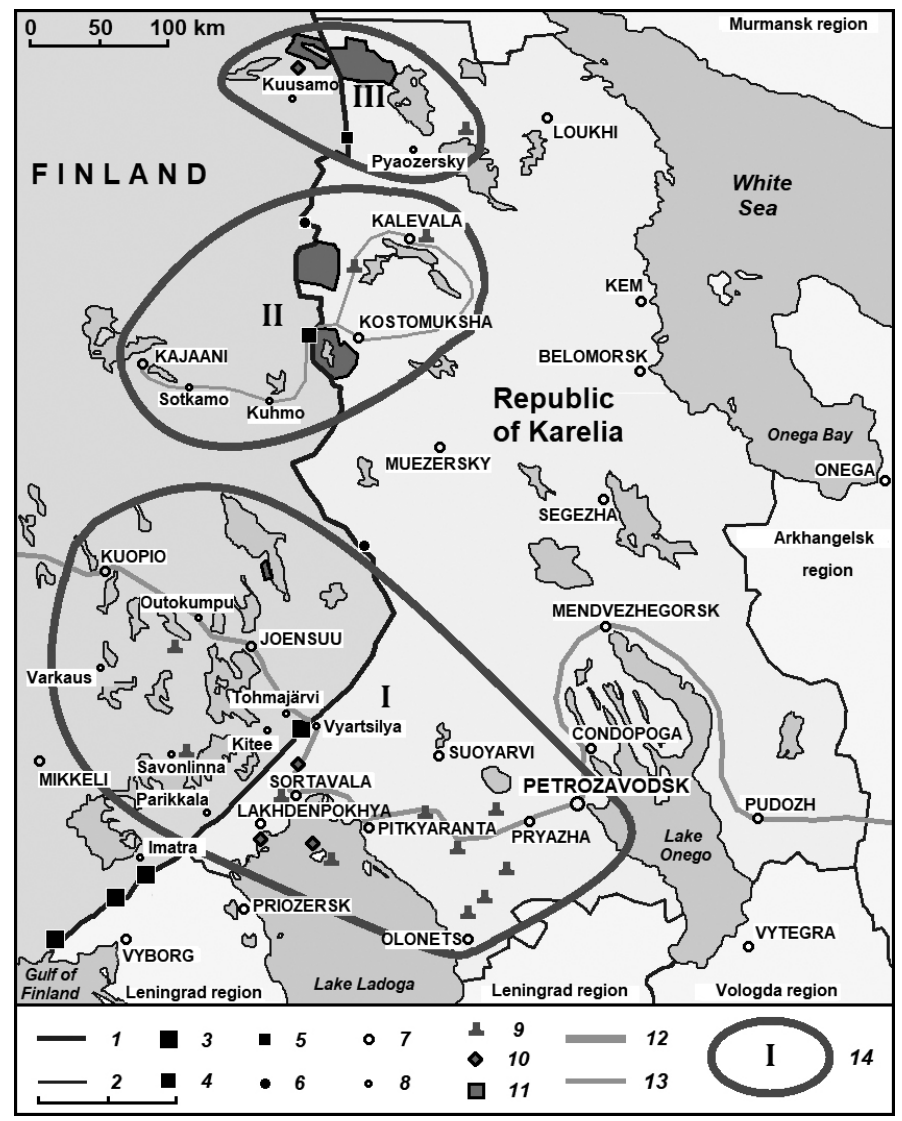

Figure 1. Transboundary tourism and recreation regions spanning bordering areas of Finland and the Republic of Karelia with market numbers (Manakov et al., 2019): Borders: 1 - national, 2 - between Russian regions; International Automobile Border-crossing Checkpoints: 3 - large, 4 - medium, 5 small; 6 - simplified procedure checkpoints; 7 - centres of regions in Finland and of administrative districts in Russia; 8 - other cities; 9 - cultural and historic landmarks; 10 - natural landmarks; 11 - national parks and strict nature reserves; transboundary tourism routes: 12 -Blue Road, 13 - The Kantele Tour Route; 14 - transboundary tourism and recreation regions: I - South Karelian (midRussian-Finnish) mesoregion, II - Mid-Karelian second-order microregion, III - North Karelian thirdorder microregion

of such nostalgic journeys of Finns (Eskelinen et al., 1994). Due to the lack of some key elements for tourism development, the Finnish tourist flow to the region dropped dramatically to just 150,000 a year in the mid-1990s (Gromov 2003; Stepanova, 2019a).

The emigration of locals from the border regions of North-West Russia to Finland played an important role in the cross-border tourism development in the Republic of Karelia. Since the first years after the collapse of the Soviet Union, emigration from Russia took the form of repatriation of ethnic Finns (Ingrians) to their historical homeland, and another noticeable feature was family reunion (Ryazantsev \& Gadzhimuradova, 2021; Sireni et al., 2021). Thanks to the so called VFR (visiting friends and relatives) migration trend, tourism in the Republic of Karelia remains high.

At the same time, a vast majority of the cross-border trips of Finns to Russia (about 


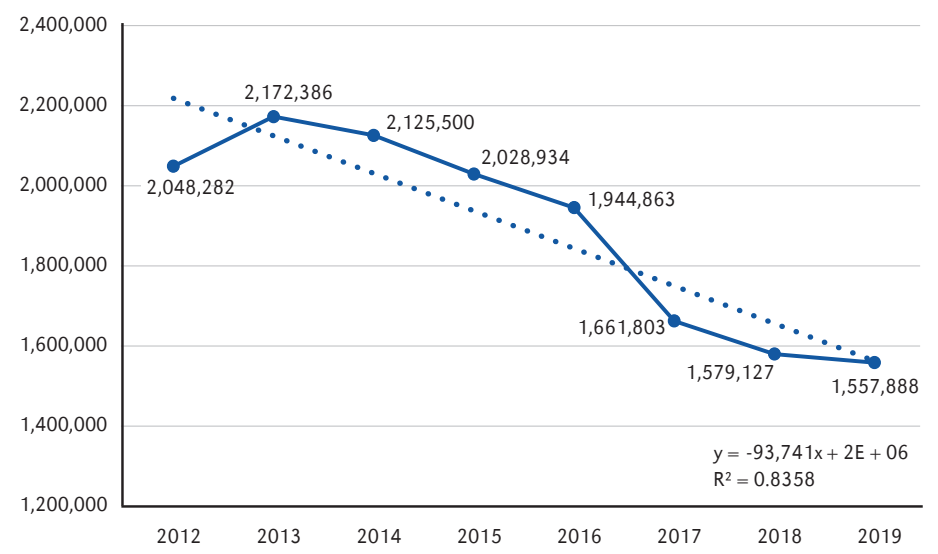

Figure 2. Changes in cross-border traffic between Finland and the Republic of Karelia during 2012-2019, number of people

Source: compiled by the Finnish Border Guard Service.

70\%), according to $\vee$. Kononenko and J. Laine (2008), had economic rationale - "in order to save money" (cheap goods, mainly alcohol, cigarettes and gasoline). The most common practice in the traffic through international check-points was short visits to the Russian borderland by Finnish travelers for shopping in "the stores and gas stations located right across the border in Russia" in the case of Torfyanovka-Vaalimaa (Leningrad Region) (Kononenko \& Laine, 2008). Or, in the case of Vyartsilya-Niirala (Republic of Karelia), the usual trips of Finns from North Karelia (Finland) to Russian Karelia for fuel could last only a few hours. Three out of four Finnish citizens visited only the border village of Vyartsilya (Björn, 2015). Other motivations for Finnish tourists to visit the Republic of Karelia are cultural, environmental, as well as economic.

In spite of the decreasing number of tourists from Finland, the share of Finns in the total inbound tourist flow to the Republic of Karelia is quite remarkable (an average of $70 \%, 2016-2019)$. The high share of Finnish tourists reveals a high dependence of the Karelian tourist industry on the dynamics of the inbound traffic from Finland as well as the challenges for the cross-border tourism development (Stepanova, 2014)

\section{Methodology and approaches}

The article is based on the sociological survey conducted from December 2019 to August 2020 in two forms: paper-based (December 2019 - March 2020) and online (JanuaryAugust 2020). After closure of the national border between Russia and Finland in March 2020 due to COVID-19, only the Googlebased form remained available for data collection. Thus, the empirical data used in this study is a set of 300 anonymous questionnaires (purposive sampling) that were conducted in the Finnish language. The median values are used in the study.

The survey addresses two matters: shoppers' perceptions of the specific conditions and the current situation, and issues related to cross-border shopping tourism. A three-section survey instrument was developed for this study. The first section comprised questions about the places of visit, frequency, duration of stay, and travel modes. The second section of the survey focused on the shopping behavior of the respondents, particularly on their purchasing behaviors, shopping frequency, shopping expenditures, and preferred goods. The last section gathered the demographic information of the respondents, such as their gender, age, occupation, residence status. 


\section{Results. Finnish cross-border tourists in the Russian Karelia \\ Portrait of the Finnish cross-border tourist}

The sample consisted of 300 respondents. In terms of gender, $38.7 \%$ respondents were females and $61.3 \%$ were males. As to the age structure, $5 \%$ were older than $29,13.3 \%$ were 30 to 39 years old, and $18.7 \%$ were 40 to 49 years old. The largest age groups of respondents were 60-69 years old and 50-59 years old (Tab. 1). Table 1 shows that the most active Finnish citizens engaged in cross-border travel to Russian Karelia are 50-70 years old. The median age of the respondents was 55 years.

Geographically, the respondents represented almost all provinces of Finland (Tab. 2, Fig. 2). The largest part of the respondents lived in North Karelia (37.0\%), mostly in Joensuu (64.9\%). The next two groups came from Northern Ostrobothnia (mainly Haapavesi and Oulu, 76.0\%) and Uusimaa (Helsinki, $67.6 \%)$. Almost equal shares of respondents lived in North and South Savo (5-6\%). Roughly one-fifth of respondents (17.6\%) were distributed among the rest of Finnish provinces, contributing insignificant shares. Only Aland Islands' residents were missing from the survey. The Republic of Karelia borders the provinces of Kainuu, Lapland, North Karelia, Northern Ostrobothnia, and South Karelia.

A quarter of the respondents were retired people, who came due to being familiar with Russian Karelia, having a good network of friends and/or relatives, as well as interests for visiting the border region, including shopping tourism (Tab. 3). Three groups of respondents with equal shares of about $16-19 \%$ were specialists, people employed in services, and education, culture and science workers. Finnish students constituted the smallest part of the visitors to Russian Karelia.

A majority of the respondents (71.0\%) have visited Russian Karelia more than ten

Table 1. Age-based groups of respondents, $\%$

\begin{tabular}{|l|c|c|c|r|r|r|}
\hline \multirow{2}{*}{ Age } & \multicolumn{3}{|c|}{ Number of respondents } & \multicolumn{3}{c|}{ Share of respondents, \% } \\
\cline { 2 - 7 } & total & women & men & total & women & men \\
\hline $22-29$ & 15 & 11 & 4 & 5.0 & 9.5 & 2.2 \\
$30-39$ & 40 & 19 & 21 & 13.3 & 16.4 & 11.4 \\
$40-49$ & 56 & 24 & 32 & 18.7 & 20.7 & 17.4 \\
$50-59$ & 76 & 30 & 46 & 25.3 & 25.9 & 25.0 \\
$60-69$ & 88 & 21 & 67 & 29.3 & 18.1 & 36.4 \\
Older 70 & 25 & 11 & 14 & 8.3 & 9.5 & 7.6 \\
\hline
\end{tabular}

Table 2. Distribution of respondents by area of residence, percentage shares

\begin{tabular}{|l|l|l|c|c|c|}
\hline Province of Finland & $\begin{array}{c}\text { Capital } \\
\text { of the province }\end{array}$ & $\begin{array}{c}\text { The nearest } \\
\text { Karelian city } \\
{[\mathrm{km}]}\end{array}$ & $\begin{array}{c}\text { Distance } \\
\text { to Petrozavodsk } \\
{[\mathrm{km}]}\end{array}$ & $\begin{array}{c}\text { Number } \\
\text { of respondents }\end{array}$ & $\begin{array}{c}\text { Share } \\
\text { of respondents } \\
{[\%]}\end{array}$ \\
\hline North Karelia & Joensuu & Sortavala, 136 & 365 & 111 & 37.0 \\
North Ostrobothnia & Oulu & Kostamuksha, 292 & 757 & 59 & 19.7 \\
Uusimaa & Helsinki & Sortavala, 500 & 727 & 44 & 14.7 \\
North Savo & Kuopio & Sortavala, 272 & 501 & 18 & 6.0 \\
South Savo & Mikkeli & Sortavala, 310 & 515 & 15 & 5.0 \\
Rest of provinces & - & - & - & 53 & 17.6 \\
\hline
\end{tabular}


Table 3. Distribution of respondents by occupation

\begin{tabular}{|c|c|c|}
\hline &  & 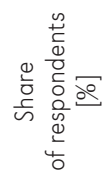 \\
\hline Retired people & 74 & 24.7 \\
\hline Specialists & 56 & 18.7 \\
\hline Services employees & 50 & 16.7 \\
\hline $\begin{array}{l}\text { Education, culture, science } \\
\text { workers }\end{array}$ & 48 & 16.0 \\
\hline Entrepreneurs & 27 & 9.0 \\
\hline $\begin{array}{l}\text { Social and health care } \\
\text { workers }\end{array}$ & 22 & 7.3 \\
\hline Unemployed & 10 & 3.3 \\
\hline Civil servants & 7 & 2.3 \\
\hline Students & 6 & 2.0 \\
\hline Total & 300 & 100 \\
\hline
\end{tabular}

times (some of them stated 30-40, or even 80 visits). The second biggest group have visited the region 6-9 times (12.33\%). The number of visits during the last year was more than five for one-third of the respondents (37.6\%, median duration of stay in the region was four days) and 2-5 for another third (34.66\%). In contrast, two groups, $17 \%$ each, have not visited the region or visited it only once during the last year. Visiting relatives and friends was one of the reasons for coming to the region for one-third of respondents (36.3\%).

Thus, the Republic of Karelia is a familiar Russian region for Finnish citizens. The research revealed some favorite cities and places to visit for Finnish travelers: Petrozavodsk, the capital of the region (62.7\%), Sortavala, a border town which used to be a Finnish settlement during the Grand Duchy of Finland time (53.0\%), and Kostomuksha, a border town built by Finns (24.7\%).

Almost all respondents (93.3\%) preferred self-organized trips to Russian Karelia. At the same time, a quarter of the trips were organized by Finnish tourist companies (24.6\%) and even Karelian travel agencies (11.0\%) (Tab. 4). The benefits of self-organized travelling are
Table 4. Distribution of respondents by travel arrangements

\begin{tabular}{|c|c|c|}
\hline &  & 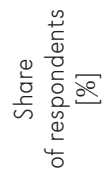 \\
\hline Self-organized travel & 284 & 94.7 \\
\hline Finnish travel agencies & 67 & 22.3 \\
\hline $\begin{array}{l}\text { Russian (Karelian) travel } \\
\text { agencies }\end{array}$ & 31 & 10.3 \\
\hline
\end{tabular}

that it is cheaper, more flexible, and allows for a pace of travel that matches travel preferences. This means that a majority of Finnish tourists are knowledgeable about the destination, are able to plan and implement the whole trip themselves.

\section{Travel preferences of Finnish tourists}

More than one-third of the respondents (37\%) were interested in visiting the Republic of Karelia for shopping tourism. It can be the main purpose of coming to the border region of Russia as well as part of a leisure trip. The median duration of stay in Russian Karelia for shopping tourists from Finland is 1.5 days (one-day trip or a longer visit). On average, visits to the region of those who point out shopping tourism as a component part of a journey last 2-3 days. When asked about reasons for travelling to the region, the respondents usually mentioned more than one reason. According to the results, a majority of the Finns (72.1\%) come to the Republic of Karelia for different kinds of tourism, including shopping. One-fifth of the tourists (20.7\%) preferred to combine shopping with activities such as event or cultural tourism, business trips, etc.

The survey showed that the Finnish tourists preferred handmade local souvenirs, especially food and beverages. The typical products taken by the Finns as souvenirs from Russian Karelia were alcohol, sweet treats (Karelian honey, Karelian herbal tea, etc.), crafts items (of Karelian birch, etc.). 
The preferred purchases for the surveyed group of Finnish tourists in the region were alcohol, food, sweet goods, as well as fuel (Tab. 5). The latter confirms the popularity of self-organized car trips to the Republic of Karelia.

Table 5. Purchases made by Finns in the Republic of Karelia

\begin{tabular}{|c|c|c|}
\hline Goods or services &  & $\begin{array}{l}\stackrel{0}{0} \\
\text { ¿ }\end{array}$ \\
\hline Alcohol & 212 & 70.7 \\
\hline Food & 177 & 59.0 \\
\hline Fuel & 161 & 53.7 \\
\hline Sweets and chocolate & 156 & 52.0 \\
\hline Clothes and cosmetics & 118 & 39.3 \\
\hline Cigarettes & 108 & 36.0 \\
\hline Other & 60 & 20.0 \\
\hline Domestic appliances & 6 & 2.0 \\
\hline
\end{tabular}

According to the data, men (19.2\%) spend more than women on their trips to the Republic of Karelia. At the same time, average extra spending for meals (40 euro) and services (30 euro) was the same for both men and women. The average difference in the amounts spent by women and by men for shopping and for other purposes was about 26 euro. Almost equal shares of respondents spent less than 20 euro (42.3\%) and 20-50 euro (39.3\%) on souvenirs and gifts from Karelia. One-fifth of the respondents spent more than 50 euros for this purpose. Souvenir shops are mostly located in the capital of the region (Petrozavodsk) and in popular tourist destinations such as Sortavala, Kizhi Open-air Museum of History, Ethnography, and Wooden Architecture (UNESCO World Heritage List), Ruskeala Mining Park, Kivach waterfalls, etc.

The main factors for the choice of accommodation facilities by Finnish travelers were the location of the hotel (74\%), the price $(60.5 \%)$, as well as the opportunities for having meals $(37.3 \%)$. One-fifth of the respondents pointed out sauna or pool as an important feature for an accommodation facility.

Cross-border tourism in the Republic of Karelia involves non-shopping activities (Tab. 6.) such as going to restaurants (64\%) or using services e.g., beauty salons and hairdressers (26.3\%) and other (6\%). Half of the Finnish travelers were looking for recreation and ways of spending leisure time participating in cultural events: visiting museums (61.3\%), theaters and concert halls (52.7\%).

Table 6. Distribution of respondents by the places they visit

\begin{tabular}{|c|c|c|}
\hline Places to visit &  & 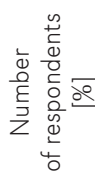 \\
\hline Restaurants & 192 & 64.0 \\
\hline Museums & 184 & 61.3 \\
\hline Theaters, concert halls & 158 & 52.7 \\
\hline Shopping centers & 140 & 46.7 \\
\hline Beauty salon, hairdresser & 79 & 26.3 \\
\hline Others & 18 & 6.0 \\
\hline
\end{tabular}

People come to Russian Karelia primarily to enjoy its beauty, which is further enhanced by the authentic architecture and traditions of the region. Petrozavodsk, situated on Lake Onego shore, is a nice green city to spend several days in and a perfect starting point for trips to Kizhi and other cultural and nature sights of the Region. The region's capital is its cultural center, with five theatres, including the Republic of Karelia National Theatre (the only one outside of Finland regularly performing plays in Finnish), several concert halls, 17 museums and art galleries.

Sortavala is the second (after Petrozavodsk) biggest tourist center in the Republic of Karelia due to its position in the RussianFinnish borderland, in the Northern Ladoga region, with natural and historical heritage (in 1721-1940 part of the Grand Duchy of Finland, within the Russia Empire). The most attractive and popular tourist destination 
in the area is the ancient Holy-Transfiguration Valaam Monastery (founded in the late $10^{\text {th }}$ to early $11^{\text {th }}$ century). Due to unique architecture, Sortavala has a historical town status in Russia (Stepanova, 2019a). A relatively new tourist attraction for Russian as well as for foreign tourists is the Ruskeala Mining Park (Nominee of the Europe's Responsible Tourism Award 2020). By the number of architectural monuments registered by government the territory of Sortavala takes the first place among the municipalities of the Republic of Karelia.

The City of Kostomuksha was founded in 1977 in connection with ore mining and was mostly built by Finnish construction companies. Thus, most objects in the territory belong to modern times, but it carries vivid traces of the culture of the two neighboring nations - Karelians and Finns. Kostomukshsky Strict Nature Reserve is famous in Finland and in some other countries for it forms the international Friendship Nature Reserve together with the Finnish Friendship Park. The Karelian-Finnish epic "Kalevala" accounts for the popularity of the tours of runo-singing settlements in Russian Karelia among Finns (Viena, 2017).

However, the language barrier for the Finnish tourist can be crucial. In our survey, one-third of respondents (28.3\%) prefers to be served in the Finnish language. Another third (35.0\%) pointed out the lack of information about tourism and leisure opportunities in the region. Besides, the Finnish travelers (29.3\%) complained about the impossibility of booking services and buying tickets online. Another hindrance for visiting Russian Karelia (mentioned by $29.0 \%$ ) is visa formalities. They have already been somewhat relaxed at the federal level via e-visa (Characteristics...). Only seven respondents (2.3\%) felt there were no obstacles for traveling to the region.

\section{Discussion}

Cross-border tourism takes an important share in the inbound tourist flow to the Republic of Karelia. The practice of cross-border tourist mobility of Finns to Russian Karelian corroborates "the significance of the neighboring countries in the structure of inbound tourist traffic" revealed by Borzyszkowski for the EU (2019). This makes the Karelian tourist industry serving inbound tourism highly dependent on the declining traffic from Finland raises the significance of the challenges for crossborder tourism.

Our findings provide interesting insights for understanding the Finnish travelers' preferences in order to stimulate the inbound tourist flow as well as the local tourism market.

A majority of the respondents in our survey preferred self-organized trips to Russian Karelia, were knowledgeable about the destination, able to plan and implement the whole trip themselves. The survey identified the typical products that the Finnish travelers brought home from the Republic of Karelia, mainly alcohol, food, sweet treats, as well as fuel. Similarly, based on Więckowski's findings (2010), one could argue that even a few hours' stay in a border region is significant for the local development. The finding relevant to the case of Southern Jutland, in which "many of the cross-border tourists visiting the region would not have come without the possibility for shopping" (Makkonen, 2016) could be applied to the practice of the Republic of Karelia (for instance, one-day trips to purchase fuel and/or foods).

The analysis reveals that the Finnish tourists (respondents) come to Russian Karelia primarily to enjoy its beauty, which is further enhanced by the authentic architecture and traditions of the region. Also, the surveyed Finns were particularly interested in experiencing Karelian culture, visiting museums, local shops and restaurants. The study confirms the results of the Konstanz, Germany - Kreuzlingen, Switzerland study (Ramsey et al., 2019) that cross-border shopping is more than simply shopping but a multilayered experience including leisure, services, atmosphere, and cultural experience.

For the surveyed group of Finns, the comfort of the holiday in general is very 
Table 7. Websites of the main Karelian tourist attractions

\begin{tabular}{|c|c|c|c|c|}
\hline Tourist attractions & Location & Website & $\begin{array}{l}\text { Translated version, } \\
\text { including calendar }\end{array}$ & Remarks \\
\hline \multicolumn{5}{|c|}{ Theatres and Concert Halls } \\
\hline Republic of Karelia National Theatre & Petrozavodsk & https://n-teatr.ru & In Finnish & Online ticket sale \\
\hline Republic of Karelia Musical Theatre & Petrozavodsk & http://mrteatr.ru/ & In English & $\begin{array}{l}\text { Online ticket sale. Available only } \\
\text { in Russian }\end{array}$ \\
\hline Republic of Karelia Puppet Theater & Petrozavodsk & http://puppet.karelia.ru/ & Only Russian version & $\begin{array}{l}\text { Online ticket sale. Available only } \\
\text { in Russian }\end{array}$ \\
\hline Philharmonic Hall & Petrozavodsk & https://kgfptz.ru/ & $\begin{array}{l}\text { In Finnish and English, partly trans- } \\
\text { lated }\end{array}$ & $\begin{array}{l}\text { Online ticket sale. Available only } \\
\text { in Russian }\end{array}$ \\
\hline Leisure Center & Sortavala & http://dk-sortavala.ru/ & Only Russian version & No online ticket sale \\
\hline Youth Social and Cultural Center & Sortavala & http://seurahuone.ru/ & Only Russian version & No online ticket sale \\
\hline $\begin{array}{l}\text { Concert Hall of the Petrozavodsk State } \\
\text { Glazunov Conservatoire }\end{array}$ & Petrozavodsk & http://glazunovcons.ru/ & In Chinese and English & No online ticket sale \\
\hline DRUZHBA Cultural and Sports Center & Kostomuksha & https://vk.com/ksc10 & Only Russian version & No online ticket sale \\
\hline \multicolumn{5}{|c|}{ Museums } \\
\hline Museum of The Polar Odysseus Club & Petrozavodsk & http://polar-odyssey.org/ & In English & No online ticket sale \\
\hline National Museum & Petrozavodsk & http://kgkm.karelia.ru & In English & No online ticket sale \\
\hline Fine Arts Museum & Petrozavodsk & https://artmuseum.karelia.ru & In Chinese and English & No online ticket sale \\
\hline $\begin{array}{l}\text { Exhibition Halls of the Kizhi Open Air } \\
\text { Museum }\end{array}$ & Petrozavodsk & http://kizhi.karelia.ru & In English & No online ticket sale \\
\hline House of the Doll Art gallery & Petrozavodsk & http://kukla.karelia.ru & Only Russian version & No online ticket sale \\
\hline Kizhi State Open Air Museum & Lake Onego & http://kizhi.karelia.ru & In English & No online ticket sale \\
\hline $\begin{array}{l}\text { Local Museum of the Northern Ladoga } \\
\text { Region }\end{array}$ & Sortavala & http://museum-sortavala.ru/ & Only Russian version & No online ticket sale \\
\hline Kronid Gogolev Private Collection Museum & Sortavala & https://www.artgogolev.ru & Only Russian version & No online ticket sale \\
\hline Karelsky Okatysh Geological Museum & Kostomuksha & - & Only Russian version & No online ticket sale \\
\hline Kostomuksha City Local Museum & Kostomuksha & https://vk.com/muskost & Only Russian version & No online ticket sale \\
\hline
\end{tabular}




\begin{tabular}{|c|c|c|c|c|}
\hline Tourist attractions & Location & Website & $\begin{array}{l}\text { Translated version, } \\
\text { including calendar }\end{array}$ & Remarks \\
\hline \multicolumn{5}{|c|}{ Nature and Mining Parks } \\
\hline Ruskeala Mining Park & Sortavala & https://ruskeala.ru/ & Only Russian version & No online ticket sale \\
\hline Valaam Archipelago National Park & Sortavala & https://valaam.ru/ & Only Russian version & No online ticket sale \\
\hline Kostomukshsky Strict Nature Reserve & Kostomuksha & https://www.kostzap.com & In Finnish and English & No online ticket sale \\
\hline \multicolumn{5}{|c|}{ Restaurants } \\
\hline Yagel & Petrozavodsk & https://yagel-ptz.ru/ & Only Russian version & $\begin{array}{l}\text { Northern cuisine restaurant, online } \\
\text { booking }\end{array}$ \\
\hline V Karelii est' & Petrozavodsk & http://tastykarjala.ru/ & Only Russian version & $\begin{array}{l}\text { Museum restaurant with Karelian } \\
\text { cuisine and collections of works by Ka- } \\
\text { relian artists and craftsmen }\end{array}$ \\
\hline Karelian Gornitsa & Petrozavodsk & https://www.gornica.ru/ & In Finnish and English & $\begin{array}{l}\text { The first and only restaurant of tradi- } \\
\text { tional Karelian cuisine }\end{array}$ \\
\hline Karelia & Petrozavodsk & http://karelia-hotel.ru/restaurant/ & In English and Chinese & Local and European food \\
\hline Piipun Piha & Sortavala & https://piipunpiha.ru/en/restaurants/ & In Finnish and English & $\begin{array}{l}\text { European, Russian and authentic } \\
\text { Karelian cuisine }\end{array}$ \\
\hline Dacha Wintera & Sortavala & https://dachawintera.ru/restaurant & Only Russian version & Karelian delis \\
\hline Lamberg & Sortavala & $\begin{array}{l}\text { http://lamberg-club.ru/restaurant. } \\
\text { html }\end{array}$ & Only Russian version & Karelian and Finnish cuisine \\
\hline Oasis & Kostomuksha & https://vk.com/oazis_rest & No website & Russian and European food \\
\hline Okey & Kostomuksha & https://okey-kosta.ru/ & Only Russian version & Japanese cuisine \\
\hline
\end{tabular}


important: accommodation, infrastructure, atmosphere. The study revealed that for the surveyed group of Finnish tourists the language barrier along with the lack of information about tourism and leisure activities as well as the lack of online booking opportunities can be crucial. Indeed, examining the websites of Karelia's major tourist attractions (Tab. 7), we can conclude that only the Republic of Karelia National Theatre and the Kostomukshsky Strict Nature Reserve provide services in Finnish. Language and communication skills also help to improve customized services and products for Finnish tourists. The official tourist web-portal of the Republic of Karelia (ticrk.ru/en/) has an English version and contains fairly comprehensive informa- tion about places to visit, accommodation and foods.

The study suggested three crucial points for the cross-border tourism development in the Russian part of the Russian-Finnish borderlands: use of the Finnish language, promotion of the Karelian destination, and online booking possibilities (Tab. 8). A comfortable tourist environment for Finnish tourists means seamless operation of all components of the tourism and hospitality industry, from visa issue and border crossing to accommodation and high-quality services to travelers.

Our study had some limitations. The selection of the respondents was limited by fact of their previous visiting of the Republic of Karelia as well as the willingness of the Finn-

Table 8. Measures to be taken by businesses, regional and local authorities to stimulate inbound tourist traffic from Finland to Russian Karelia

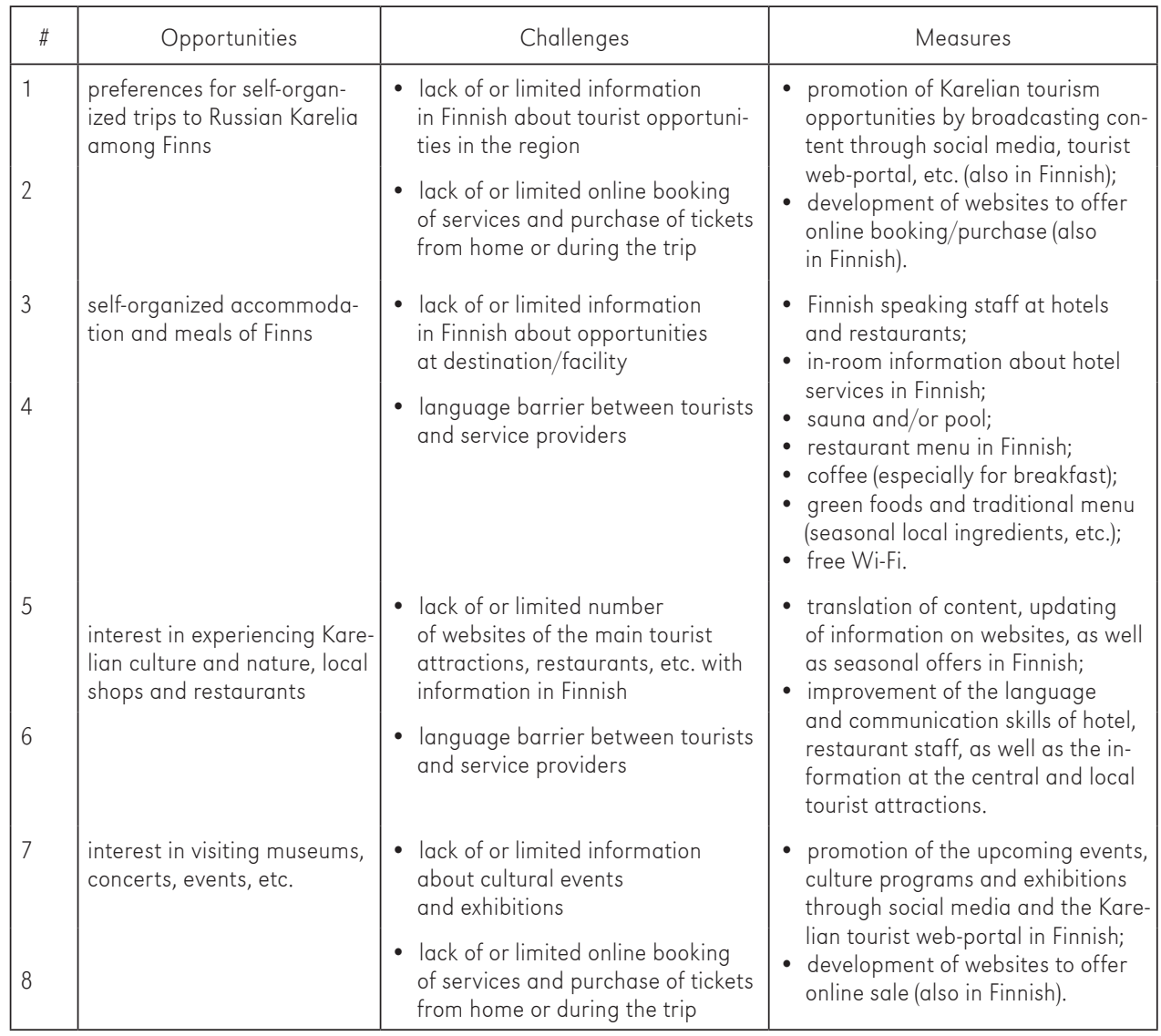


ish travelers to take part in the sociological survey. We could not interview one-day crossborder shopping tourists near the international checkpoint Vyartsilya-Niirala as planned because the Russian-Finnish border was closed due to COVID-19. Therefore, our results cannot be generalized to all Finns and should be interpreted with caution. Despite these limitations, the study offers an insight into the preferences of Finnish tourists travelling to the Russian borderland region, which can be used to improve Karelian tourist products by providing services as expected by tourists.

The focus in future studies will be on opportunities as well as challenges of the cross-border tourism development in Karelian borderlands from the perspective of local authorities, businesses, and locals.

\section{Conclusions}

The Republic of Karelia is a thoroughly familiar and an interesting Russian region for the surveyed group of Finnish travelers. The borderline location with its historical, cultural and social conditions, and economic reasons, are the key factors attracting citizens of Finland to the region. Although cross-border tourists constitute a significant part of the inbound tourist flow to Russian Karelia, several obstacles for this type of tourism have been revealed. The lack of information about tourism and leisure activities in English and Finnish, the impossibility of booking services and buying tickets online, the language barrier (Finnish) can be handled. Measures for stimulating the inbound flow of Finnish tourists are suggested for businesses (accommodations, restaurants, museums, travel companies, etc.), tourist attractions, as well as for regional and local authorities. The results may have a wider relevance for other border regions interested in maintaining or increasing tourist traffic from the neighboring country.

\section{Acknowledgements}

The authors are grateful to the reviewers for the constructive and helpful comments and suggestions.

The authors wish to express their personal appreciation to Tatiana Islamaeva (Head of the Finnish Language Center in the Republic of Karelia), Diana Seppä (Head of the Russia-Finland Society Branch in Haapavesi, Finand), Anna Härkönen (Karelia Expert Tourist Service Ltd., Joensuu), Natalya Lavrushina (Head of the Karelian Public Diplomacy Development Foundation, Petrozavodsk), Vera Meshko (Head of the Swedish-Karelian Business and Information Center), Armas Mashin (Editor-in-chief of the Carelia magazine), Olga Gokkoeva (Head of the House of the Karelian Language, Vedlozero Village, Republic of Karelia - Oulu, Finland) for their help with distributing the questionnaire. We are thankful to Elena Bagaeva (Director of Karelika Travel Company, Petrozavodsk), Prof. Olga Hannonen (University of Eastern Finland, Joensuu), as well as Jari K. Nenonen (Geological Survey of Finland, Kuopio) for their help, expertise and language check of the questionnaire. The questionnaire was posted in the following groups in Facebook: branches of the Russia-Finland Society in Helsinki, Lieksa, Haapavesi, Russian travelers, Russian readers, Karelia Expert Tourist Service Ltd. The authors wish to thank all the respondents who took part in the survey.

Thanks to Prof. Andrey G. Manakov (Pskov State University, Russia) for creating Figure 1.

Special thanks to Olga Kislova (Chief Translator, Karelian Research Center, Russia) for thorough language review of the text.

The paper was prepared under state assignment to the Karelian Research Centre of the Russian Academy of Sciences.

\section{Editors' note:}

Unless otherwise stated, the sources of tables and figures are the authors', on the basis of their own research. 


\section{References:}

2018 Schengen Visa statistics by third country. Retrieved from https://statistics.schengenvisainfo. com/2018-schengen-visa-statistics-third-country/ [6 September 2020].

Björn, I. (2015). Border province: The main features of the development of North Karelia after World War II. Studia Humanitatis Borealis, 5(2), 4-16.

Boonchai, P., Freathy, P. (2020). Cross-border tourism and the regional economy: A typology of the ignored shopper. Current Issues in Tourism, 23(5), 626-640. https://doi.org/10.1080/13683500.2018.1548579

Borzyszkowski, J. (2019). Neighboring countries - an important segment in inbound tourism - an example of the European Union member states. WSB Journal of Business and Finance, 53(1). https://doi.org/10.2478/WSBJBF-2019-0001

Breiby, M.A., Duedahl, E., Øian, H., Ericsson, B. (2020). Exploring sustainable experiences in tourism. Scandinavian Journal of Hospitality and Tourism, 20(4), 335-351. https://doi.org/10.1080/15022250.2020.1748706

Characteristics of the unified e-visa and conditions for its issuance. MFA Russia Consular department. Retrieved from https://evisa.kdmid.ru/\# [11 August 2021]

Chow, C.K.W., Tsui, W.H.K. (2019). Cross-border tourism: Case study of inbound Russian visitor arrivals to China. International Journal of Tourism Research, 21(5), 693-711. https://doi.org/10.1002/jtr.2297

Eskelinen, H., Oksa, J., Austin, D. (Eds.). (1994). Russian Karelia in search of a new role. Joensuu: Karelian institute, University of Joensuu.

Europe's Responsible Tourism Award 2020. Retrieved from https://www.worldtravelawards.com/award-europes-responsible-tourism-award-2020

Gromov, V.V. (2003). Vozdejstvie turizma na razvitie regiona (The impact of tourism on the development of the region). Petrozavodsk: Scandinavia. (in Russian)

Gurova, O. (2012). Počemu peterbužcy otpravlâûtsâ za pokupkami v Finlândiû? Issledovanie transgraničnogo šopinga (Why do city dwellers from St. Petersburg go shopping to Finland? A Study of crossborder shopping). Ekonomicheskaya sotsiologiya / Economic sociology, 13(1), 18-37. (in Russian)

Gurova, O., Ratilainen, S. (2015). 'Turist s vostoka': očerk o vospriâtii rossijskogo potrebitelâ finskoj pressoj ('Tourist from the East': Perceptions of Russian consumer by Finnish printed media). Ekonomicheskaya sotsiologiya / Economic Sociology, 16(3), 26-45 (in Russian)

Gurova, O., Ratilainen, S. (2016). From shuttle traders to middle-class consumers: Russian tourists in Finnish newspaper discourse between the years 1990 and 2014. Scandinavian Journal of Hospitality and Tourism, 16(1), 51-65. https://doi.org/10.1080/15022250.2016.1244507

Hannonen, O. (2016). Peace and quiet beyond the border: The trans-border mobility of Russian second home owners in Finland. University of Eastern Finland, Joensuu.

Izotov, A., Laine, J. (2013). Constructing (un)familiarity: Role of tourism in identity and region building at the Finnish-Russian border. European Planning studies, 21(1), 93-111. https://doi.org/10.1080/09654313.2012.716241

Kolosov, V., Więckowski, M. (2018). Border changes in Central and Eastern Europe: An introduction. Geographia Polonica, 91(1), 5-16. http://doi.org/10.7163/GPol.0106

Kononenko, V. Laine, J. (2008). Assessment of the Finnish-Russian border: The case of Vaalimaa border crossing point. The Finnish Institute of International Affairs. https://www.files.ethz.ch/isn/92091/wp57.pdf

Kostiainen, A. (1999). The vodka trail: Finnish travellers' motivation to visit the former Soviet Union. In Travel patterns: Past and present. Three studies (pp. 33-48). http://www.genealogia.fi/emi/art/article263e.htm [17 August 2021] 
Kusdibyo, L. (2016). Examining souvenir shopping tourists behaviour across cultures. In Proceedings of the Asia Tourism Forum 2016 - the 12th Biennial Conference of Hospitality and Tourism Industry in Asia (pp. 317-321). https://doi.org/10.2991/atf-16.2016.47

Käyhty, A. (1999). The Russians are coming - and Lappeenranta rubs its hands. Helsingin Sanomat, 20.

Laine, J. (2017). Finnish-Russian border mobility and tourism: Localism overruled by geopolitics. In D. Hall (Ed.), Tourism and geopolitics: Issues and concepts from Central and Eastern Europe (pp. 178-190). Wallingford: CABI. https://doi.org/10.1079/9781780647616.0178

Laine, J.P.,Van der Velde, M. (2017). Spiritually ours, factually yours: Karelia and Russia in Finnish public consciousness. Europa Regional, 24(1/2). https://www.ssoar.info/ssoar/handle/document/54451

Lauren, K. (2014). Facing the otherness: crossing the Finnish-Soviet Estonian border as narrated by Finnish tourists. Culture Unbound. Journal of Current Cultural research, 6(6), 1123-1143. https://doi.org/10.3384/cu.2000.1525.1461123

Li, L.H., Cheung, K.S., Han, S.Y. (2018). The impacts of cross-border tourists on local retail property market: an empirical analysis of Hong Kong. Journal of Property Research, 35(3), 252-270. https://doi.org/10.1080/09599916.2018.1511628

Makkonen, T., Williams, A., Weidenfeld, A. Kaisto, V. (2018). Cross-border knowledge transfer and innovation in the European neighbourhood: Tourism cooperation at the Finnish-Russian border. Tourism management, 68, 140-151. https://doi.org/10.1016/j.tourman.2018.03.008

Makkonen, T. (2016). Cross-border shopping and tourism destination marketing: The case of Southern Jutland, Denmark. Scandinavian Journal of Hospitality and Tourism, 16(1), 36-50. https://doi.org/10.1080/15022250.2016.1244506

Malkowski, A., Mickiewicz, B., Malkowska, A. (2020). Shopping tourism as a Factor in the development of peripheral areas: The case of the Polish-German borderland. European Research Studies Journal, 23(3), 238-248.

Manakov, A.G., Kondrateva, S.V., Terenina, N.K. (2020). Development of cross-border tourist and recreational regions on the Karelian section of the Russian-Finnish border. Baltic Region, 12(2), 140-152. https://doi.org/10.5922/2079-8555-2020-2-9

McKenzie, B. (2016). Vodka Tourism in Estonia: Cultural Identity or Clearly Commerce? Travel and Tourism Research Association: Advancing Tourism Research Globally. 70.

https://scholarworks.umass.edu/ttra/2011/Visual/70

Mitríková, J., Šenková, A., Antolikova, S., Parová, V. (2016). The analysis of shopping behaviour in the context of spending leisure time activities of consumers in the chosen shopping centres in Vienna (Austria). Economic Annals-XXI, 161(9-10), 71-74. https://doi.org/10.21003/ea.V161-16

Nesterova, I.S. (2009). Prigraničnaâ torgovlâ sel'skogo naseleniâ Velikogo knâžestva Finlândskogo i Vostočnoj Karelii (Cross-border trade of the rural population of the Grand Duchy of Finland in Karelia). Učenye zapiski Petrozavodskogo gosudarstvennogo universiteta, 5, $24-29$ (in Russian)

Nesterova, I.S. (2012). Karel'skie torgovcy v Velikom knâžestve Finlândskom (Karelian traders in the Grand Duchy of Finland). In Grani sotrudničestva: Rossiâ i Severnaâ Evropa (The dimensions of cooperation: Russia and Northern Europe) (pp.301-308). Petrozavodsk: Petrozavodskij gosudarstvennyj universitet. (in Russian)

Objects of cultural heritage in the Republic of Karelia. Retrieved from http://monuments.karelia.ru/ob-ekty-kul-turnogo-nasledija/ [17 August 2021]. (in Russian)

Order of the Federal Security Service of Russia of August 7, 2017 No 454, "On approval of the rules of the border regime". Retrieved from http://www.consultant.ru/document/cons_doc_LAW_282173/ [11 August 2021]. (in Russian)

Prokkola, E.-K. (2010). Borders in tourism: The transformation of the Swedish-Finnish border landscape. Current Issues in Tourism, 13(3), 223-238. https://doi.org/10.1080/13683500902990528 
Prokkola, E.-K. (2019). Border-regional resilience in EU Internal and External border areas in Finland. European Planning Studies. https://doi.org/10.1080/09654313.2019.1595531

Ramsey, D., Thimm, T., Hehn, L. (2019). Cross-border shopping tourism: A Switzerland-Germany case study. European Journal of Tourism, Hospitality and Recreation, Sciendo, 9(1), 3-17.

Russians spent almost 23 billion rubles in borderland Finland in 2017. Retrieved from https://sanktpeterburg.bezformata.com/listnews/rossiyane-za-2017-god-potratili/67825251/ [4 August 2021] (in Russian)

Ryazantsev, S.V., Gadzhimuradova, G. (2021). Russophone immigration to Finland: New forms, trends, and consequences. Baltic region. 13(2), 146-164. https://doi.org/10.5922/2079-8555-2021-2-8

Shikalov, J.G. (2016). Istoriâ v formirovanii regional'noj identičnosti žitelej g.Vyborga v sovetskij i postsovetskij periody (Regional identity development of Vyborg population in the Soviet and Post-Soviet periods). Učenye zapiski Petrozavodskogo gosudarstvennogo universiteta, 5(158), 13-20. (in Russian)

Shikalov, Y., Hämynen, T.(2013). Viipurin kadotetut vuodet 1940-1990.Helsinki: Tammi.

Sireni, M., Pöllänen, P., Davydova-Minguet, O. (2021). Invisible agents of rural development. Russian immigrant women in the Finnish border region. Frontiers in Sociology, 6: 601726. https://doi.org/10.3389/fsoc2021.601726

Spierings, B., van der Velde, M. (2013). Cross-border differences and unfamiliarity: shopping mobility in the Dutch-German Euro region. European Planning Studies. 21: 1, 5-23. https://doi.org/10.1080/09654313.2012.716236

Stepanova, S.V. (2014). Cross-border tourism in the Russian Northwest: General trends and features of development. Baltic Region, 3, 109-120. https://doi.org/10.5922/2079-8555-2014-3-10

Stepanova, S.V. (2019a). The Northern Ladoga region as a prospective tourist destination in the RussianFinnish borderland: Historical, cultural, ecological and economic aspects. Geographia Polonica, 92(4), 409-428. https://doi.org/10.7163/GPol.0156

Stepanova, S.V. (2019b). Czynniki rozwoju turystyki przygranicznej na rosyjsko-fińskim pograniczu (Factors underpinning the development of tourism in Russian-Finnish borderland areas). Przeglad Geograficzny, 91(4), 573-587. https://doi.org/10.7163/PrzG.2019.4.7.

Stepanova, S.V., Shlapeko, E.A. (2018). Trends in the development of cross-border trade in the RussianFinnish borderland. Baltic Region, 10(4), 103-117. https://doi.org/10.5922/2079-8555-2018-4-7

Studzinska, D., Sivkoz, A., Domaniewski, S. (2018). Russian cross-border shopping tourists in the Finnish and Polish borderland. Norwegian Journal of Geography, 72(2), 115-126. http://doi.org/10.1080/00291951.2018.1451365

Su, X., Spierings, B., Hooimeijer, P., Scheider, S. (2020). Where day trippers and tourists go: Comparing the spatio-temporal distribution of Mainland Chinese visitors in Hong Kong using Weibo data. Asia Pacific Journal of Tourism Research, 25(5), 505-523. https://doi.org/10.1080/10941665.2020.1741409

Szytniewski, B., Spierings, B., van der Velde, M. (2017). Socio-cultural proximity, daily life and shopping tourism in the Dutch-German border region. Tourism Geographies. 19(1), 63-77. https://doi.org/10.1080/14616688.2016.1233289

Szytniewski, B., Spierings, B. (2018). Place image formation and cross-border shopping: German shoppers in the Polish bazaar in Słubice. Tijdschrift voor Economische en Sociale Geografie, 109(2), 295-308. https://doi.org/10.1111/tesg.12283

The Border Guard in Figures, The Finnish Border Guide. Retrieved from https://www.raja.fi/prime103_en.aspx/current_issues/statistics [6 September 2020]

The official tourist portal of the Republic of Karelia. Retrieved from http://www.ticrk.ru/en/ [6 September 2020]

Timothy, D.J., Butler, R.W. (1995). Cross-border shopping: A North American perspective. Annals of Tourism Research, 22(1), 16-34. https://doi.org/10.1016/0160-7383(94)00052-T 
Vanhatalo, A., Niemela, P., Kuuluvainen, T., Vasander, H. (Ed.). (2017). Viena vieköön-matka kalevalaiseen luontoon ja kulttuuriin. Helsinki: Helsingin yliopisto, 256.

Więckowski, M. (2010). Tourism development in the borderland of Poland. Geographia Polonica, 83(2), 67-81.

Więckowski, M., Cerić, D. (2016). Evolving tourism on the Baltic Sea coast: Perspectives on change in the Polish maritime borderland. Scandinavian Journal of Hospitality and Tourism, 16(1), 98-111.

https://doi.org/10.1080/15022250.2016.1244598 